\title{
PERENCANAAN PARTISIPATIF PARIWISATA TAMAN WISATA AIR (SKEMA PENDAMPINGAN SKEMA PEMANFAATAN TEKNOLOGI TEPAT GUNA (TTG) DI TIRTOHARGO, KECAMATAN KRETEK KABUPATEN BANTUL)
}

\author{
Muhamad Muhamad ${ }^{1}$ \\ ${ }^{1}$ Sekolah Pascasarjana Universitas Gadjah Mada Yogyakarta \\ email : drmuhammad@ugm.ac.id \\ Wiryanto $^{2}$ \\ Sekolah Vokasi , Universitas Gadjah Mada Yogyakarta \\ maswir@ugm.ac,id \\ Hastangka $^{3}$ \\ Sekolah Pascasarjana Universitas Gadjah Mada \\ hastangka30@ugm.ac.id
}

\begin{abstract}
Abstrak
Isu tentang perencanaan partisipatif dalam peningkatan ekonomi masyarakat untuk kemajuan pembangunan menjadi isu menarik sejak menguatnya otonomi daerah. Fokus perhatian tentang perencanaan partisipatif dimulai dari arus demokrasi yang menguat paska reformasi telah mendorong hadirnya peran partisipasi masyarakat dalam pembangunan. Studi ini akan membahas dan mendiskusikan tentang perencanaan partisipatif peningkatan ekonomi masyarakat untuk kemajuan pembangunan. Fokus kajian dilakukan pada pemerintah desa Tirtohargo yang merasa perlu dalam pemanfaatan sumber daya lahan (SDA) di desa tersebut. Kegiatan ini dilaksanakan pada 2 Agustus 2017 di mulai dengan menyampaikan gagasan Harmonisasi Among Tani Dagang Layar untuk meningkatkan kesejahteraan rakyat Daerah Istimewa Yogyakarta. Among Tani Dagang Layar terdiri atas tiga pengertian yaitu pembangunan daratan beralih ke lautan, menjadikan pantai selatan sebagai halaman depan, dan mengenalkan kepada masyarakat akan budaya perikanan. Artinya gayung bersambut antara usaha pengembangan ekonomi masyarakat dan pelestarian konservasi potensi air yang dilakukan oleh Desa Tirtohargo melalui pemberdayaan masyarakat dengan apa yang disampaikan Gubernur Daerah Istimewa Yogyakarta. Pada tahun 2020, pantai Selatan merupakan prioritas utama bagi pembangunan di Yogyakarta Selatan. Metode pelaksanaan dalam studi ini dilakukan secara partisipatif dengan Focus Group discussion (FGD) warga masyarakat secara partisipatif. Hasil yang dicapai dalam penelitian ini menunjukkan bahwa upaya untuk mengembangkan parencanaan partisipatif taman wisata air ini dilakukan tidak hanya dengan melibatkan masyarakat, akan tetapi juga menjalin kerjasama dengan berbagai pihak, baik instansi, lembaga maupun swasta. Peran berbagai pihak diharapkan mampu menyokong dari mulai proses perencanaan partisipatif hingga pelaksanaan partisipatif. Partisipatif masyarakat sangat tinggi dalam perencanaan partisipatif pariwisata.
\end{abstract}

Kata Kunci : Perencanaan Partisipatif, Taman Wisata Air.

\section{PENDAHULUAN}

Perencanaan partisipatif pariwisata untuk peningkatan ekonomi masyarakat daklam pembangunan merupakan fokus Pemerintah Desa pada saat ini . Hal yang mendasari perlunya dalam pemanfaatan sumber daya lahan (SDA) di desa tersebut. Fokus model partisipatif ini pada tanggal 2 Agustus 2017 didukung gagasan Harmonisasi Among Tani dagang Layar untuk meningkatkan 
kesejahteraan rakyat Daerah Istimewa Yogyakarta.

Among Tani Dagang Layar terdiri atas tiga pengertian yaitu pembangunan daratan beralih ke lautan, menjadikan pantai selatan sebagai halaman depan, dan mengenalkan kepada masyarakat akan budaya perikanan. Artinya dayung bersambut antara usaha pengembangan ekonomi masyarakat dan pelestarian konservasi potensi air yang dilakukan dkawasan laut selatan melalui pemberdayaan masyarakat dengan apa yang disampaikan Gubernur Daerah Istimewa Yogyakarta. Pada tahun 2020 ini pantai Selatan merupakan prioritas utama bagi pembangunan di Yogyakarta Selatan.

Upaya untuk mengembangkan parencanaan partisipatif pariwisata taman wisata air ini dilakukan tidak hanya dengan melibatkan masyarakat, akan tetapi juga menjalin kerjasama dengan berbagai pihak, baik instansi, lembaga maupun swasta. Andil berbagai pihak diharapkan mampu menyokong dari mulai proses perencanaan partisipatif hingga pelaksanaan perencanaan partisipatif pariwisata.

Potensi wisata air di Desa Tirtohargo, Kecamatan Kretek Kabupaten Bantul sangat melimpah terutama potensi air tawar yang difungsikan sebagai PAMSIMAS. Program Nasional Penyediaan Air Minum dan Sanitasi Berbasis Masyarakat (PAMSIMAS) Penyediaan Air Minum dan Sanitasi Berbasis Masyarakat (PAMSIMAS) adalah salah satu program yang dilaksanakan oleh Pemerintah Indonesia dengan dukungan Bank Dunia, program ini dilaksanakan di wilayah perdesaan dan pinggiran kota. Pamsimas merupakan asset masyarakat yang dikelola oleh masyarakat sehingga $100 \%$ menjadi milik masyarakat.

Melalui pemberdayaan masyarakat dan skema pendamnpingan Pemanfaatan Teknologi Tepat Guna (TTG) mengajak masyarakat Desa Tirtohargo untuk turut andil di dalam kegiatan Pendampingan Perencanaan pengembangan pariwisata di Taman Wisata Air Tirtohargo. Upaya untuk mengembangkan parencanaan partisipatif ini dilakukan tidak hanya dengan melibatkan masyarakat, akan tetapi juga menjalin kerjasama dengan berbagai pihak, baik instansi, lembaga maupun swasta. Andil berbagai pihak diharapkan mampu menyokong dari mulai proses perencanaan partisipatif hingga pelaksanaan partisipatif.
Dari latar belakang tersebut diatas, tumbuh kepedulian bersama terhadap lingkungan yaitu dengan mengembaangkan perencanaan secara partisipatif dalam pengembangan pariwisata. Pengembangan pariwisata berbasis pada atraksi, amenitas dan pengembangan aksesibilitas, Yoeti, H. Oka A. dkk, (2006). Model pengelolaanya berbasis masyarakat lokal guna untuk menciptakan sistem perlindungan alamiah yang mampu mengurangi atau menyelesaikan berbagai permasalahan yang dihadapi kawasan sekitar Pamsimas. Proses perencanaan partisipatif masyarakat memiliki posisi yang sangat penting dalam perencanaan pembangunan, karena pada dasarnya masyarakat adalah pihak yang paling mengetahui masalah dan kebutuhannya sendiri. oleh karena itu perencanaan pembangunan yang partisipatif menjadi amanat undang-undang yang harus di laksanakan oleh pelaku pembangunan.

Melalui Peraturan Pemerintah No. 72/2005 (Pasal 64) tentang Desa, dan Permendagri No. 66/2007 tentang Perencanaan Pembangunan Desa, memberi amanah kepada pemerintah desa untuk menyusun program pembangunannya sendiri. Forum perencanaannya disebut sebagai Musyawarah Perencanaan Pembangunan Desa (Musrenbang Desa). Maksud pelaksanaan kegiatan Perencanaan Partisipatif Detail Enginering Desain Taman Wisata Air di Tirtohargo ini antara lain: 1) satu adalah, Bagaimanakah melakukan Pendampingan Perencanaan Partisipatif pengembangan pariwisata Taman Wisata Air Tirtohargo Kretek Bantul agar sesuai dengan fungsi dan peruntukannya dengan memperhatikan daya dukung dan daya tampung lingkungannya dan mampu mampu menjadi daya tarik pariwisata, 2) kedua adalah, bagaimanakah menghasilkan dokumen pendampingan perencanaan partisipatif pariwisata Taman Wisata Air di Tirtohargo yang mampu menjadi daya tarik pariwisata.

Dari latar belakang tersebut diatas maka kegiatan Perencanaan Partisipatif pariwisata di Tirtohargo Kretek Bantul sangat diperlukan untuk mendapatkan dokumen Pendampingan Perencanaan Partisipatif pengembangan pariwisata Taman Wisata Air yang lengkap yang akan di jadikan dasar bagi pelaksanaan pembangunan Taman Wisata Air yang mampu menjadi daya Tarik wisata terutama 
bagi masyarakat sekitar.

\section{METODE PELAKSANAAN KEGIATAN}

Perencanaan partisipatif dalam pengembangan pariwisata adalah sebuah pendekatan untuk memberikan kesempatan masyarakat lokal untuk terlibat langsung dalam pengembangan daya Tarik wisata atau atraksi , (Muhamad dan Widyarini , 2020). Metode pelaksnaan kegiatan pendampingan perencanaan partisipatif pengembangan pariwisata Taman Wisata Air di Tirtohargo Kretek Bantul dengan Focus group Discussion.

Pelaksanaan metode demikian, karena jumlah peserta FGD tidak banyak maka hasil FGD tidak dapat digeneralisasikan atau digunakan sebagai kesimpulan umum untuk populasi atau kelompok yang lebih luas dari peserta FGD, walaupun mempunyai ciri-ciri atau karakteristik peserta FGD. Pelaksanan FGD dilaksnakan dengan struktur keterlibatan pemerintahan desa dan kelompok masyarakat seperti dibawah ini.

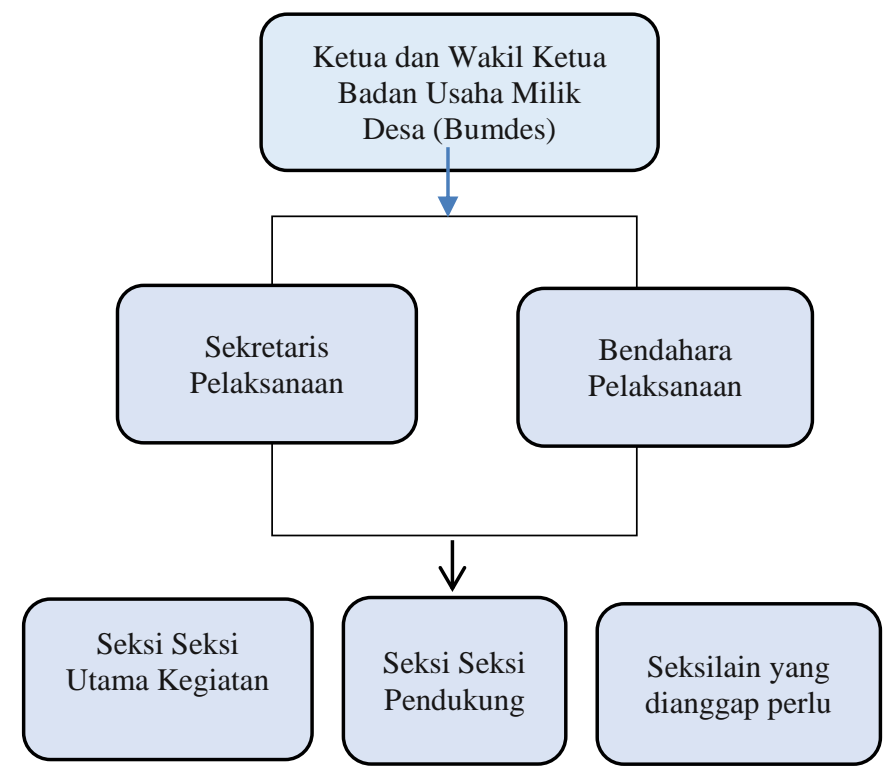

Gambar 1. Struktur Keterlibatan Pemerintahan Desa dan Kelompok Masyarakat Desa Tirtohargo,

Kecamatan Kretek, kabupaten Bantul.

Sumber: Analisis Penelitian, 2021

Langkah-langkah pelaksanaan metodologi sebagai berikut : a. Persiapan FGD dengan adanya

Tabel 1; Program Terjadwal Pelaksnaan Focus Group Disscussion dengan Pemerintahan Desa Tirtohargo, fasilitator dan pencatat sebagai notulensi harus datang tepat waktu sebelum peserta datang. Fasilitator dan pencatat (notulen) sebaiknya bercakap-cakap secara informal dengan peserta, sekaligus mengenal nama peserta dan yang menjadi perhatian fasilitator maupun pencatat.

Sebelum FGD dilaksanakan perlu ada persiapan-persiapan sebagai berikut (Krueger, 1988): 1. Menentukan jumlah kelompok FGD Untuk menentukan jumlah kelompok yang dibutuhkan perlu ditetapkan terlebih dahulu hipotesa topik yang akan diteliti. Misalnya apakah jenis kelamin, umur, pendidikan, status sosial ekonomi penting bagi topik penelitian. Pedoman dalam menentukan jumlah kelompok: a) Minimal 2 kelompok pada tiap kategori. Misalnya melaksanakan 2 kelompok pada tiap-tiap segmen populasi, seperti kelompok pengguna pelaksanaan pendampingan.

\section{HASIL DAN PEMBAHASAN}

Perencanaan partisipatif merupakan perecanaan yang bertujuan melibatkan kepentingan masyarakat lokal, Rocharungsat, Pimrawee, (2008), dan dalam prosesnya melibatkan masyarakat (baik langsung maupun tidak langsung). Oleh karenanya salah satu indikator keberhasilan pembangunan adalah adanya partisipasi masyarakat penerima program, Muhamad Muhamad (2020).

Pelaksnaan awal dengan melakukan kegiatan survei ke lokasi kegiatan dan kelompok sasaran dengan tim pendampingan dan pemerintah Desa Tirtohargo secara terjadwal dan terprogram melalui rutinitas dalam pertemuan yang disepkati Bersama. Pelaksanaan awal terjadwal secara langsung untuk melakukan observasi di lokasi pelaksanaan. 


\begin{tabular}{lllllllllllll}
\hline \multicolumn{10}{c}{ Kecamatan Kretek, Kabupaten Bantul. } \\
\hline 1 & 2 & 3 & 4 & 5 & 6 & 7 & 8 & 9 & 10 & $\begin{array}{l}\text { Observasi, evaluasi tujuan, } \\
\text { pelaksanaan FGD }\end{array}$ & topik \\
\hline 11 & 12 & 13 & 14 & 15 & 16 & 17 & 18 & 19 & 20 & $\begin{array}{l}\text { Ringkasan cara kerja dan Langkah kerja } \\
\text { terintegrasi }\end{array}$ \\
\hline 21 & 22 & 23 & 24 & 25 & 26 & 27 & 28 & 29 & 30 & $\begin{array}{l}\text { Rencana khusus pembahasan secara } \\
\text { periodik }\end{array}$ \\
\hline
\end{tabular}

Sumber; Analisis Pelaksanaan FGD, 2021

Pada minggu awal bulan pelaksnaan pada minggu pertama $(1,2,3,4)$ Minggu pertama pelaksanaan survey lokasi pelaksnaan Pengembangan dan evaluasi tujuan dan topik FGD. Merancang idea dan gagasan secara terpadu hasil diskusi dengan pemerintahan desa dengan Membuat ringkasan metodologi yang akan dilakukan, waktu penelitian, biaya dan detail implementasi seperti lokasi pelaksanaan kegiatan, spesifikasi perencanaan serta topik dan topik secara khusus yang akan dibahas.

Ringkasan cara kerja dan langkah kerja terintegrasi merupakan langkah upaya bagaimana melibatkan masyarakat dalam bekerja secara partispatori dan menentukan titik duga secara factual di lokasi kegiatan. Kegiatan dilaksanakan dengan beberapa tahapan yang dilakukan $(13,14$, 15) proses ini menggabungkan berbagai metode dan cara kerja perencanaan secara partisipatif. Rencamna khusus secara periodic ini mengintegrasikan Langkah Langkah kerja dalama Menyusun perencanaan misalnya ; bagaimana menerapkan tujuan yang menghasilkan dokumen pelaksanaan yaitu: 1) satu adalah, menghasilkan dokumen pelaksanaan pendampingan perencanaan partisipatif pengembngan pariwisata pada Taman Wisata Air di Tirtohargo Kretek Bantul, 2) kedua adalah, menghasilkan dokumen pendampingan perencanaan partisipatif pengembangan pariwisata dalam penyusunan Anggaran Biaya dan spesifikasi pelaksanaan Pendampingan Perencanaan Partisipatif pengembangan pariwisata Taman Wisata Air di Tirtohargo Kretek Bantul, 3) ketiga adalah, menghasilkan tata laksana waktu pelaksanaan Pendampingan Perencanaan Partisipatif pengembangan pariwisata) Taman Wisata Air di Tirtohargo Kretek Bantul.
Pelaksanaan Proses Focus Group Disscusion (FGD) dihadiri oleh badan usaha milik desa, artinya, suatu lembaga/badan perekonomian desa yang berbadan hukum dibentuk dan dimiliki oleh Pemerintah Desa, dikelola secara ekonomis mandiri dan profesional dengan modal seluruhnya atau sebagian besar merupakan kekayaan desa yang dipisahkan. Bumdes di Desa Tirtohargo sendiri dimaksudkan untuk memperoleh keuntungan di mana selanjutnya dapat memperkuat Pendapatan Asli Desa (PADes), memajukan perekonomian desa, serta meningkatkan kesejahteraan masyarakat desa seperti menurut Peraturan Pemerintah Nomor 72 Tahun 2005 tentang Desa pasal 78 ayat (1). Keberadaan Bumdes menjadi salah satu usaha atas permasalahan-permasalahan yang terjadi di desa terutama di lingkup kesejahteraan.
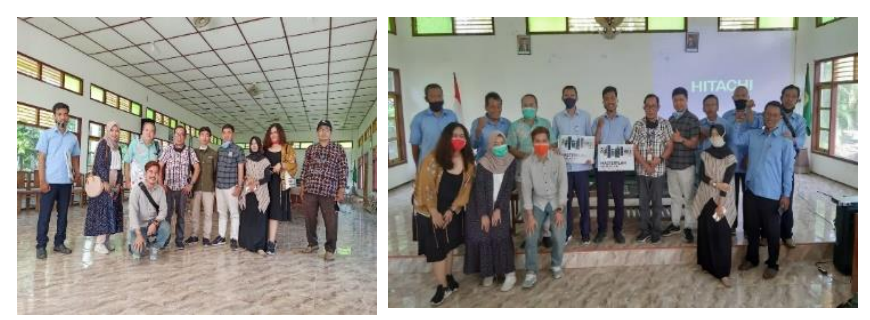

Gambar 2 : Pelaksanaan Proses Focus Group Disscusion (FGD) dengan Badan Usaha Milik Desa (Bumdes) yang Melibatkan Kelompok Terpenting Di Desa Tirtohargo, Kecamatan Kretek, Kabupaten Bantul

Sumber: Dokumentasi Penelitian, 2020 .

Pada minggu awal bulan pelaksnaan ke 2 pada minggu pertama tanggal (4,5,6) Minggu pertama pada pelaksanaan minggu ke 2 , mulailah proses perencanaan secara partisipatif dengan pelibatan masyarakat sekitar. Proses ini diawali dengan melihat kondisi aksesibilitas dari dan menuju lokasi kegiatan dan proses pentahapan 
pekerjaan dengan menyusun program kerja sebagai berikut : a. Persiapan (studi literatur), b.Penjadwalan kegiatan survei pendahuluan, c. Penjadwalan diskusi di desa setempat dengan masyarakat, d.Kompilasi data yang di perlukan dalam penyusunan dalam Perencanaan Partisipatif, e.Survei lahan dan kawasan untuk mengetahui kondisi eksisting, f.Survei kondisi sosial ekonomi masyarakat, g.Analisa teknis dari berbagai aspek terkait, i. Matrik masukan dari masyarakat hasil FGD.

Proses pendampingan perencanaan partisipatif pengembangan pariwisata di Taman Wisata Air di Tirtohargo Kretek Bantul maka faktor-faktor yang perlu mendapatkan pengkajian pada tahap minggu berikutnya tanggal $(11,12,13,21)$ yaitu dengan menentukan hal-hal pokok untuk disepakati bersama yaitu, menentukan beberapa hal, sebagai berikut: 1) satu adalah , penetuan sistem zonasi dan pembagian fungsi ruang melakukan klasifikasi masing masing fungsi ruang sesuai peruntukannya seperti: rencana site plan, rencana denah untuk kolam renang antara dewasa dan anak-anak, ruang ganti, ruang bilas , mushola, ruang parkir, gudang alat dsb. 2) kedua adalah, struktur Peruntukan Lahan menyangkut: Peruntukan lahan kawasan sekitar perlu untuk diketahui (persawahan, peternakan, perladangan dll), Pembagian blok kawasan untuk penataan ruang
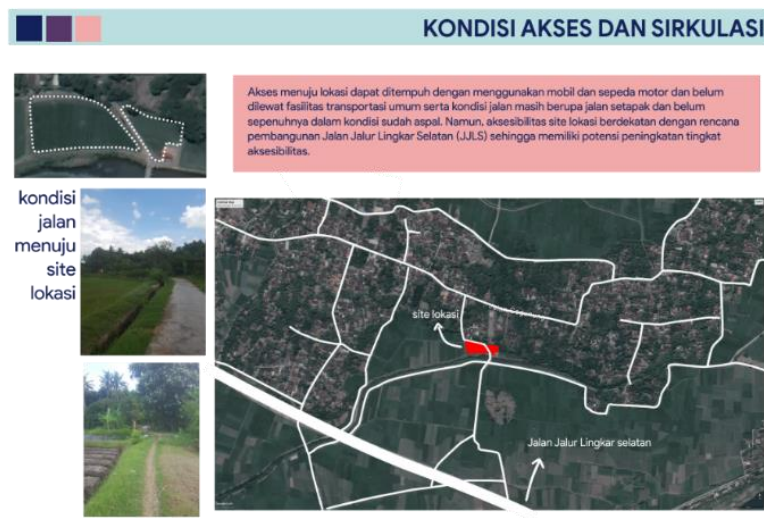

Gambar 3 : Sistem Aksesibilitas ke lokasi kegiatan merupakan factor penting dalam menentukan titik lokasi perencanaan partisipatif.

Sumber; Analisis Penelitian, 2020
Hasil masukan dari diskusi dengan pemerintahan desa pada bulan pelaksanaan kedua merupakan penilaian terhadap berbagai keadaan yang dilakukan berdasarkan prinsip-prinsip, pendekatan dan metode serta teknik analisis yang dapat di pertanggungjawabkan untuk di lanjutkan pada tahapan pekerjaan selanjutnya dengn menggunakan alat bantu teknis

Gambar 4 : Sistem site plan kawasan dan peta kawasan dan batas batas kawasan., dan system aktifias yang kan direncanakan.

Sumber; Analisis Penelitian, 2020

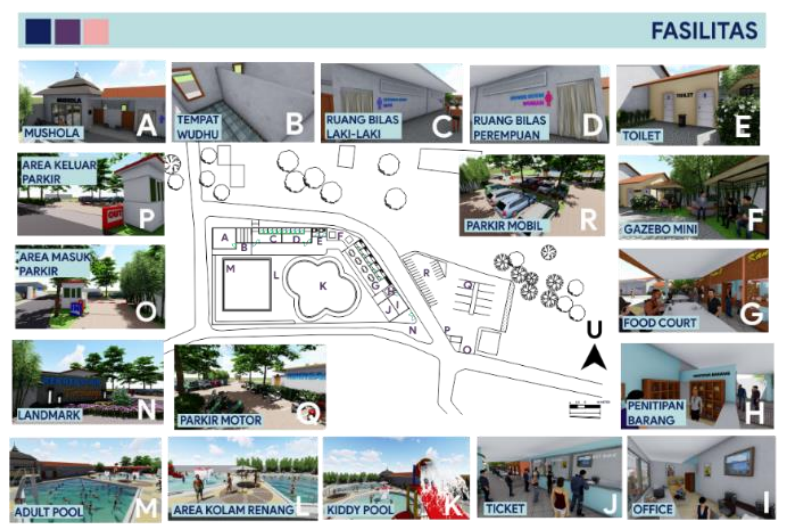


Tabel 2; Program Terjadwal Pelaksanaan Focus Group Disscussion (FGD) dengan Pemerintahan Desa Tirtohargo, Kecamatan Kretek, Kabupaten Bantul.

\begin{tabular}{lllllllllll}
\hline \multicolumn{7}{c}{ Bulan Pelaksanaan } & & & Keterangan \\
\hline 1 & 2 & 3 & 4 & 5 & 6 & 7 & 8 & 9 & 10 & Proses perencanaan partisipatif \\
\hline 11 & 12 & 13 & 14 & 15 & 16 & 17 & 18 & 19 & 20 & Proses perencanaan partisipatif \\
\hline 21 & 22 & 23 & 24 & 25 & 26 & 27 & 28 & 29 & 30 & Proses perencanaan partisipatif \\
\hline
\end{tabular}

Sumber; Analisis Pelaksanaan FGD, 2021

\section{Pada tahapan akhir pelaksnaan} terinventarisasi rencana dokumen akhir yang berisi materi final yang merupakan penyempurnaan proses pelaksanaan pertama yang telah mengakomodir masukan-masukan pada proses perencanaan partisipatif tertanggal $(21,25,26,28)$ - Perencanaan partisipatif yang menhasilkan rumusan akhir dalam bentuk Dokumen Perencanaan Kegiatan Perencanaan Partisipatif pengembangan pariwisata di Taman Wisata Air di Tirtohargo Kretek Bantul adalah sebagai berikut :

Tabel 3; Inventarisasi Dokumen Perencanaan Partisipatif Detail Enginering Desain Taman Wisata Air yang merupakan hasil FGD secara partisipatif.

\begin{tabular}{|c|c|c|}
\hline Nama fungsi ruang & Jml & Skala \\
\hline Analisis kondisi umum & $2 \mathrm{bh}$ & $1: 5000$ \\
\hline $\begin{array}{lcr}\text { Site plan kawasan dan peta } \\
\text { kawasan } \\
\text { kawasan. }\end{array}$ & 2 buah & $1: 5000$ \\
\hline Kondisi umum dan Potensi & $1 \mathrm{bh}$ & $1 ; 5000$ \\
\hline $\begin{array}{l}\text { Denah Dewasa dan anak anak } \\
\text { dan denah secara keseluruhan } \\
\text { kawasan }\end{array}$ & $2 \mathrm{bh}$ & 1: 200 \\
\hline $\begin{array}{l}\text { Tampak sisi utara selatan-timur } \\
\text { dan barat }\end{array}$ & 4 buah & $1: 200$ \\
\hline $\begin{array}{l}\text { Potongan sisi utara selatan dan } \\
\text { potongan sisi timur dan barat }\end{array}$ & 4 buah & $1: 200$ \\
\hline $\begin{array}{l}\text { Rencana struktur pondasi kolam } \\
\text { Dewasa dan anak anak }\end{array}$ & 2 buah & $1: 200$ \\
\hline Rencana Pondasi kawasan & 2 buah & 1: 200 \\
\hline $\begin{array}{l}\text { 1) Rencana Pondasi Musholla, 2) } \\
\text { Rencana Pondasi tempat wudhlu, } \\
\text { 3) Rencana Pondasi Ruang Bilas } \\
\text { laki laki 4) 5) Rencana Pondasi } \\
\text { Ruang Bilas Perempuan, 6) toilet, } \\
\text { 7) Gazebo Mini, 8) Food court, 9) } \\
\text { Ruang Locker, 10 Tetenger, 11) }\end{array}$ & 8 buah & $1: 200$ \\
\hline
\end{tabular}

\begin{tabular}{|c|c|c|}
\hline Nama fungsi ruang & Jml & Skala \\
\hline $\begin{array}{l}\text { Rencana Pondasi Kolam renang } \\
\text { dewasa dan anak }\end{array}$ & & \\
\hline $\begin{array}{l}\text { Rencana Pola lantai keseluruhan } \\
\text { kawasan dan bangunan }\end{array}$ & 2 buah & $1: 200$ \\
\hline $\begin{array}{l}\text { 1) Rencana atap Musholla, 2) } \\
\text { Rencana atap tempat wudhlu, 3) } \\
\text { Rencana atap Ruang Bilas laki } \\
\text { laki 4) 5) Rencana atap Ruang } \\
\text { Bilas Perempuan, 6) toilet, 7) } \\
\text { rencana atap Gazebo Mini, 8) } \\
\text { rencana atap Food court, 9) } \\
\text { rencana atap Ruang Locker, 10 } \\
\text { Tetenger, 11) Rencana atap } \\
\text { Kolam renang dewasa dan anak }\end{array}$ & 8) buah & $1: 200$ \\
\hline $\begin{array}{l}\text { Rencana Vegetasi kawasan dan } \\
\text { pola sirkulasi kawasan }\end{array}$ & 2 buah & 1: 500 \\
\hline $\begin{array}{lll}\text { Rencana system } & \text { sanitasi } & \text { dan } \\
\text { utilitas kawasan } & & \\
\end{array}$ & 2 Buah & 1: 500 \\
\hline $\begin{array}{l}\text { Rencana system dan detail detail } \\
\text { struktur dan arsitektur }\end{array}$ & $\begin{array}{l}5 \\
\text { buah }\end{array}$ & $1: 500$ \\
\hline $\begin{array}{lll}\text { Rencana } & \text { Anggaran } & \text { Biaya }\end{array}$ & & \\
\hline $\begin{array}{l}\text { Pelaksanaan Pembangunan; } \\
\text { pekerjaan struktur, pekerjaan } \\
\text { arsitektural, pEkerajaan plumbing } \\
\text { dan sanitasi }\end{array}$ & & \\
\hline \begin{tabular}{llr} 
Rencana & \multicolumn{2}{c}{ Spesifikasi bahan } \\
bangunan & dan penggunaan \\
material & &
\end{tabular} & & \\
\hline Schedule pekerjaan keseluruhan & & \\
\hline
\end{tabular}

Tabel diatas merupakan rumusan yang diperoleh dari hasil Focus Group Discussion (FGD) dengan pemerintahan Desa Tirtohargo yaitu Bumdes Desa Tirtohargo yang akan memberikan data dan informasi yang dibutuhkan untuk kegiatan perencanaan partisipatif dalam pengembangan fasilitas pariwisata dan ikut terlibat 
dalam perencanaan partisipatif. Selain akan memfasilitasi dalam hal koordinasi dengan instansi terkait untuk mendapatkan data dan informasi yang di butuhkan. Produk yang dihasilkan dalam perencanaan yang sesuai dengan keluaran yang diinginkan akan menghasilkan produk yang optimal. Pemberi tugas adalah Pemerintah Desa Tirtohargo yang diberi tanggung jawab menyelenggarakan melalui mekanisme dan prosedur pelaksanaan secara swakelola oleh Bumdes Desa Tirtohargo Kretek Bantul.

\section{KESIMPULAN}

Potensi pengembangan pariwisata khususnya wisata air sangat melimpah terutama ketersediaan sumber daya alam (SDA) potensi air tawar yang difungsikan sebagai PAMSIMAS. Program Nasional Penyediaan Air Minum dan Sanitasi Berbasis Masyarakat (PAMSIMAS). Penyediaan Air Minum dan Sanitasi Berbasis Masyarakat (PAMSIMAS) adalah salah satu program yang dilaksanakan oleh Pemerintah Indonesia dengan dukungan Bank Dunia, program ini dilaksanakan di wilayah perdesaan dan pinggiran kota yang merupakan asset masyarakat yang dikelola oleh masyarakat sehingga $100 \%$ menjadi milik masyarakat dan dapat dikembangkan menjadi daya tarik wisata. Pada tahapan akhir pelaksnaan terinventarisasi rencana dokumen akhir yang berisi materi final yang merupakan penyempurnaan proses pelaksanaan pertama yang telah mengakomodir masukan-masukan pada proses perencanaan partisipatif. Perencanaan partisipatif yang menhasilkan rumusan akhir dalam bentuk Dokumen Perencanaan Kegiatan Perencanaan Partisipatif pengembangan pariwisata di Taman Wisata Air merupakan usaha pemanfaatan sumber daya alam yang dimanfaatkan untuk aktifitas berwisata.

\section{UCAPAN TERIMA KASIH}

Sekolah Pascasarjana Universitas Gadjah Mada Yogyakarta, Program Studi Magister Kajian Pariwisata (Program S2)

Direktotat Pengabdian Kepada Masyarakat (DPKM) Universitas Gadjah Mada Yogyakarta melalui Skema Pengembangan dan Pemanfaatan Teknologi Tepat Guna (TTG

\section{DAFTAR PUSTAKA}

Krueger, Richard A. 1988. FOCUS GROUPS: A Practical Guide for Applied Research. SAGE Publications. California.

Undang-undang Nomor 10 tahun 2009, Tentang Kepariwisataan, Kementrian Pariwisata Republik Indonesia

Muhamad Muhamad (2021), Participatory Planning Of Tourist Train Station Accessibility And Creative Industry Development, Jurnal Nasional Terakreditasi, Universitas Udayana Bali, Jurnal e- Tourism, Volume 8, DOI: Https://Doi.Org/10.24922/Eot.V8i1.71450, ISSN/Eissn E-ISSN:2407-3942X

Muhamad Muhamad (2021), Creative Tourism in The Era of New Normality in The Advancement of Culture, , Jurnal Nasional Terakreditasi, Universitas Udayana Bali, Jurnal e- Tourism, Volume 8, DOI: Https://Doi.Org/10.24922/Eot.V8i1.71450, ISSN/Eissn E-ISSN:2407-3942X

Muhamad Muhamad, Widya Rini , (2021) Partisipasi Masyarakat pada Penerapan Pembangunan Pariwisata Berkelanjutan (Studi Kasus Desa Wisata Pujon Kidul, Kabupaten Malang), Jurnal 'Pariwisata' Terapan,(Vol.(3,(No.(2, 2019) Sekolah Vokasi, Universitas Gadjah Mada Yogyakarta.

Muhamad Muhamad (2021), Study of city public open space elements as an urban tourism (case study of public open space in Yogyakarta City, Prosiding, IOP Conference Series: Earth and Environmental Science 3rd International Seminar on Livable Space, ISSN/ISBN $780 \quad$ 012062, Universitas Trisakti, Jakarta.

Muhamad Muhamad, Widya Rini (2020), Design 
of Tourism Development in Cultural Corridors and Public Spaces in Kraton Yogyakarta Area, IOP Conference Series: Earth and Environmental Science 452 (2020) 012046 IOP Publishing doi:10.1088/17551315/452/1/012046, ISSN/ISBN 10.1088/1755-1315/452/1. https://iopscience.iop.org/issue/1755$1315 / 452 / 1$

Muhamad Muhamad, Saryani (2021), Monitoring of the tourism village of the mount merapi slope area through the Global Sustainable Tourism Council (GSTC) snapshoot assessment system, IGEOS (International Geofraphy), , Universitas Sebelas Maret Surakarta (UNS), IOP Conference Series: Earth and Environmental Science, doi:10.1088/1755-1315/683/1/01211, https://iopscience.iop.org/issue/1755$1315 / 683 / 1$

Muhamad Muhamad, (2021), Tourism Accesibility System Planning And Creative Indsutry Tourism Village Potentials Development, Directorate of Community Services Universitas Gadjah Mada Yogyakarta, The international 2 nd Conference on Community Engagement and Education For Sustainable Development, ISBN, 978-602-51728-0-9, https://pengabdian.ugm.ac.id/2020/10/13/651 8.

Mukhlison, Wiryanto, Muhamad Muhamad (2021) , Creative Economy and Mangrove Baros Ecotourism Development based on Social Capital in Tirtohargo Village, Bantul Province, Directorate of Community Services Universitas Gadjah Mada Yogyakarta, The international 2 nd Conference on Community Engagement and Education For Sustainable Development, ISBN, 978-602-51728-0-9, https://pengabdian.ugm.ac.id/2020/10/13/651 8 .

Peraturan Pemerintah No. 72/2005 (Pasal 64) tentang Desa, dan Permendagri No. 66/2007 tentang Perencanaan Pembangunan Desa,
Rocharungsat, Pimrawee, (2008), Community Based Tourism in Asia, in: Moscardo, Gianna. (eds) Community Capacity for tourism development, USA: CABI.

Siti Nurul Rofiqo Irwan1, Hani Perwitasari, Muhamad Muhamad, Pendampingan Identifikasi Potensi Pengembangan Agrowisata Berbasis Partisipasi Masyarakat di Desa Tirtomulyo, Kretek, Bantul, Yogyakarta (Community Assistance to Identify the Potential of Community Participation-Based Agro-tourism Development in Tirtomulyo Village, Kretek, Bantul, Yogyakarta), Jurnal Agro Kreatif, Institu Pertanian Bogor, Juni 2021, Vol 7 (2): $122 \square 130$ Jurnal Ilmiah Pengabdian kepada Masyarakat, ISSN 2460-8572, EISSN 2461-095X

Subejo, S; Nurul Chamidah; Nirmala Sari; Suyoto HS,. Sunarru Samsi Hariadi, Muhamad, (2021)')Strategi Komunikasi dan Pemanfaatan Teknologi Informasi dan Komunikasi dalam Pengembangan Desa Wisata pada Masa Pandemi Covid-19 di Cirebon, Jurnal ketahanan Nasional, Sekolah Pascasarjana Universitas Gadjah Mada Yogyakarta, Volume 27 No. 1, April 2021 Halaman 90-111 https://doi.org/10.22146/jkn.61859

Yoeti, H. Oka A. dkk, (2006), Pariwisata Budaya: Masalah dan solusinya, Jakarta: PT. Pradnya Paramita. 